\title{
Mathematical Modeling for Performance Prediction of a Humidification - Dehumidification Solar Water Desalination System in Egypt
}

\author{
H. H. El-Ghetany ${ }^{*}$ and N.M. Khattab \\ Solar Energy Department, National Research Centre, Dokki, \\ 12622, Giza, Egypt.
}

\begin{abstract}
A SIMPLE water desalination system using humidification$A$ dehumidification process (HDH) enhanced with solar energy was theoretically studied. In the presented system, a double jacket solar water storage tank was used to heat the saline water in a separate independent circuit. A natural circulation solar water cycle between the flat plate collector and the storage tank was introduced to prevent salt scales formation inside the internal boundary layers of the flat plate collector tubes and heating system network. The humid air in the atomization chamber was collected on the condenser surface that cooled by water using thermoelectric refrigeration technique. This refrigerator was powered by a DC electric source provided by a solar photovoltaic module to maximize the water yield. The simulation model was built using the local meteorological conditions of Cairo, Egypt ( $30^{\circ} 2^{\prime} \mathrm{N}$ latitude, $31^{\circ} 14^{\prime} \mathrm{E}$ longitude). Results showed that the daily production of condensed water depended on the flow rate and temperature of saline water in addition to air mass flow rate and its pressure. It is found that the maximum productivity of the system is achieved in summer season with a value of $64.3 \mathrm{~L} /$ day and it is found that each $\mathrm{kWh} / \mathrm{m}^{2} /$ day falling on the collector surface produced 7.9 L/day. Although the produced quantity of desalinated water is small, yet it can help inhabitants especially in rural and remote areas where potable water is unavailable to be kept survived. Moreover, this system could be replicated to produce more desalinated water for inhabitants demand. As Egypt enjoys long coastal area of about 2500 $\mathrm{km}$ in length as well as abundant solar energy most time of the year will encourage the Egyptian government to install several solar water desalination plants with several technologies. One of the most promising and simple technologies is the HDH Process.
\end{abstract}

Keywords: Water desalination, Solar energy, Humidificationdehumidification, Thermoelectric refrigeration and Heat exchanger.

Humidification-Dehumidification (HDH) process for water desalination is considered a simple and promising technique for small capacities production units. The basic idea in (HDH) process is to mix air with water vapor followed by extracting water from the humidified air through the condenser. Advantages of HDH units are: low-temperature operations, ability to combine with

* Corresponding author e-mail: hamdy.elghetany@gmail.com 
renewable energy sources such as solar energy, with low level of requirements of technical features. Using solar energy sources in water desalination has many advantages and benefits. The most common advantage of renewable energy is its sustainability and that it cannot be depleted. Moreover, it is a clean source of energy, keeps the air free of pollutants, and reduces global warming or greenhouse gas emissions. Because its source is natural, operational costs are limited. Applying these resources in water desalination in remote areas represents the best option due to its high cost of providing energy from the grid. Several systems based on the principle of HDH using solar energy have been installed in many areas of the world. Al-Hallaj et al. ${ }^{(1)}$ concluded that the basic principle of all these techniques was that evaporation of seawater and condensation of water vapor from the humid air took place in the unit at ambient pressure and at temperatures between $40^{\circ} \mathrm{C}$ and $85^{\circ} \mathrm{C}$. They also concluded from the economic point of view that the solar HDH process was a suitable replacement to all other forms of solar desalination techniques in the smaller capacity range. Abdel Dayem and Fatouh ${ }^{(2)}$ investigated various solar desalination systems to find out the most efficient one. They compared three systems experimentally and numerically under climatic conditions of Cairo, to determine the suitable system that can be commercially introduced. They found also that the solar open system with natural circulation was more efficient regardless of practical difficulties. In addition, the closed system using an auxiliary heater had the highest distilled water production. Yildirım and Solmus ${ }^{(3)}$ introduced a theoretical study to investigate the effects of the various operating and design parameters, such as: air, feed water and cooling water mass flow rates. They also detected cooling water temperature and collector tilt angle on clean water production rate of the closed water-open air cycled HDH desalination system under the climatological conditions of Antalya, Turkey. They found that the maximum amount of annual clean water yield was obtained as the collector tilt angle was approximately adjusted to angle of latitude. They observed also that water heating has a major importance on clean water production due to the fact that heat capacity of water was higher than that of air. That meant that heating of air with solar air heater didn't lead to any significant improvement on clean water production as it was compared to heating of the water with solar water heater. Additional remark was the clean water production found to be positively affected by the increasing air mass flow rate and feed water mass flow rate with an optimum point for air mass flow rate and an increase in air mass flow rate certainly caused a decrease in clean water production. Generally, the annual clean water production can be multiplied with about 12 tons of clean water over the specified operating parameters. Enayatollah et $a l^{(4)}$ presented a theoretical model to optimize a novel humidification-dehumidification desalination system and found that a maximum of production rate of $1.5 \mathrm{~kg} / \mathrm{hr} . \mathrm{m}^{2}$ was achieved; however it was also found that this rate was particularly influenced by the incident radiation, the inlet water temperature and the water flow rate. El-Said and Kabeel ${ }^{(5)}$ presented theoretical study of a nano-fluid solar collector assisted -hybrid desalination system for small community's needs. They found that seven main parameters have

Egypt. J. Chem. 59, No. 2 (2016) 
influence on the system productivity; feed water mass flow rate of SSF unit, feed water mass flow rate of HDH units, cooling water mass flow rate of single-stage flashing evaporation (SSF) unit, cooling water mass flow rate of HDH units, air mass flow rate, inlet cooling water temperature and nano-particle volume fraction. Their results show that, the studied hybrid desalination system gives a significant operational compatibility between the air humidification dehumidification method and flash evaporation desalination with daily water production up to $112.5 \mathrm{~kg} / \mathrm{day}$. Orfi et al. ${ }^{(6)}$ presented theoretical analysis and experimental investigation of a humidification dehumidification water desalination system using solar energy. Their theoretical results identified an optimum mass flow rate ratio corresponding to a maximum fresh water product. The aim of the present work is to build up a mathematical model to predict the performance evaluation and study the affecting parameters on the daily water produced from the system throughout the year as per $\mathrm{kWh} / \mathrm{m}^{2} /$ day falling on the collector surface of the solar water heater as a heating source of the hot water entering the atomization chamber.

\section{System description}

A solar water heater shown in Fig. 1 with double jacket heat exchanger is used to heat the saline water stored inside the storage tank. The thermosiphonic water passed in a separate loop from the collector, through the annular space of the water jacket heat exchanger and returned back to the collector. It means that there is no direct contact between the water in the thermosiphonic water loop and the saline water. This pathway is to prevent any salt or scales formation in the collector tube. The hot saline water is mixed with a pressurized air passed from air compressor and makes atomization of the hot water in the atomization chamber. Large numbers of water droplets with fine cross sectional area were spread in the atomization chamber. Some portions of the atomized hot water were evaporated and the others were fallen by gravity in the installed bottom basin as shown in Fig 1. The hot saline water passed through the heat exchanger preheats the inlet clod raw water prior entering the solar heater. Two water cooled condensers were installed in the side wall of the atomization chamber to condense the water vapor formed in the atomization chamber. In order to create cold surface in the condenser side, cold water was passed through the condenser tubes coming from a galvanized steel tank placed in its bottom a thermoelectric refrigeration cooling unit which received its DC electric energy from a solar PV module. The cooling effect was provided to the water galvanized steel tank then pumped into the condenser tubes via circulating pump. The humid air was passed through the condenser surface. It was drafted to the atmosphere through a DC blower that electricity fed by the solar PV module.

\section{Mathematical modeling of the system components}

The presented mathematical model of the proposed system shows the energy balance equation by taking input energy terms equal to output energy terms. For the energy balance and governing equations for each of the system components, 
the following assumptions are taken into consideration during the simulation process:

1- The distillate vapor always condenses completely.

2- The system is behaved in a quasi-steady-state manner and one dimensional; i.e. the variables, while varying from hour to hour, are considered constant during every hour of analysis and the unsteady terms in the governing equations are neglected ${ }^{(5)}$.

3- The atomization chamber contains the humidifier (evaporator) and dehumidifier (condenser).

4- It is assumed that each component has an average temperature that is dependent on the inlet water temperature.

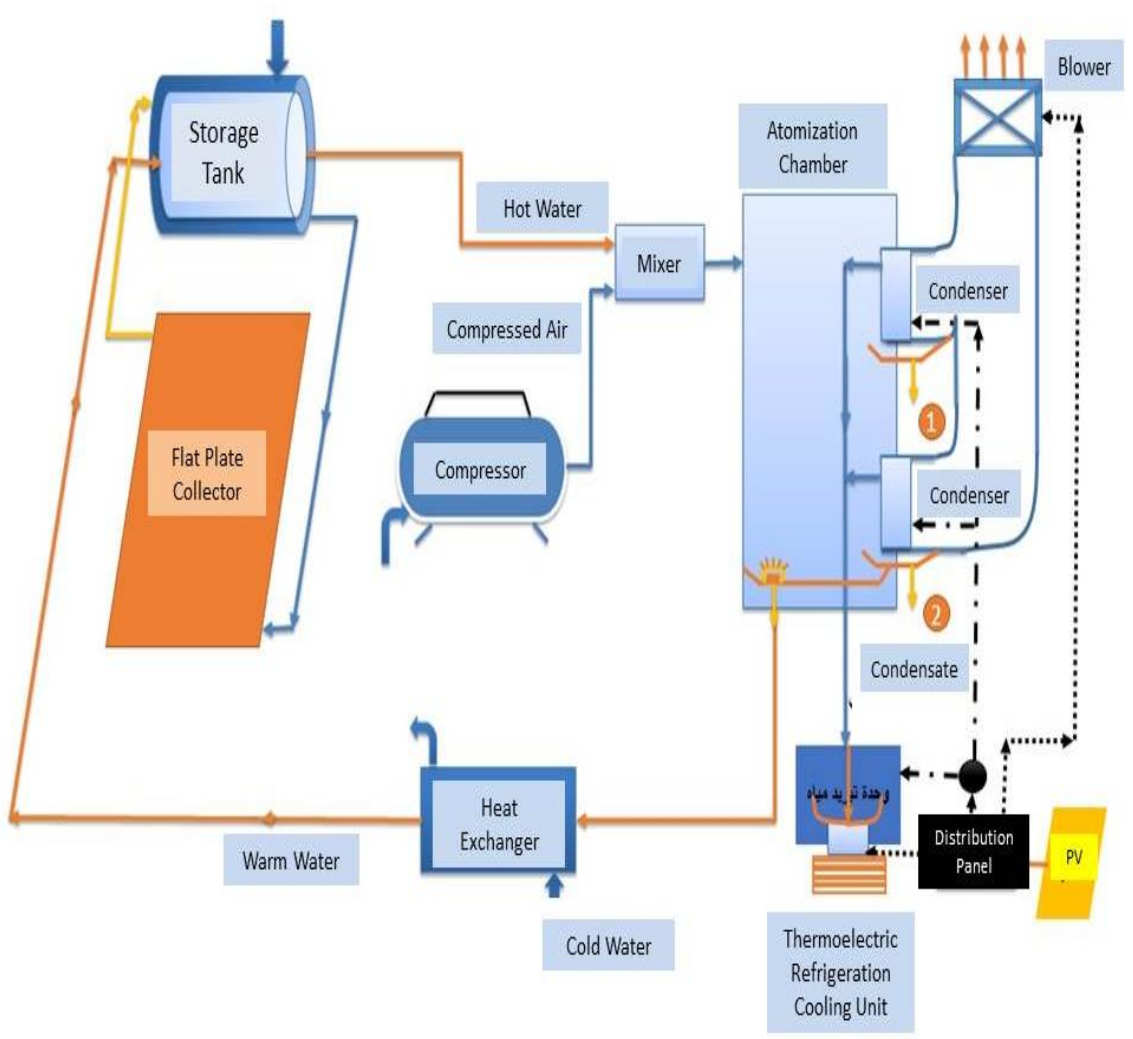

Fig. 1. Layout of a humidification-dehumidification solar water desalination system.

The model was used to simulate and predict the water production of the desalination system over a $24 \mathrm{hr}$ period, as the hot water source is coming from 
the hot water solar storage tank. Based on the above mentioned assumptions, the energy-conservation equations are expressed as given in the following sections:

\section{Solar water heater}

The solar water-heating system under investigation consists of a flat-plate solar collector, horizontal storage tank with a surrounding jacket, connection pipes, valves, and frame. The flat-plate solar collector consists basically of an absorbing surface, an insulation layer, anodized-aluminum section casing and a transparent cover. The collector effective area is $2.0 \mathrm{~m}^{2}$. The absorbing surface is covered with black paint and insulated from the bottom and sides by $4 \mathrm{~cm}$ polyurethane insulation layer to reduce heat losses and inserted in a casing and covered with transparent glass of $4 \mathrm{~mm}$ thickness. The storage tank has two concentric stainless steel cylindrical vessels welded together from top to bottom. The inner vessel is of $39 \mathrm{~cm}$ diameter and $100 \mathrm{~cm}$ length which represents the storage tank, the outer vessel has a $41 \mathrm{~cm}$ diameter and the same length as the inner vessels. The annular space between the concentric vessels is considered to be the heat exchanger, which is filled with the carrier fluid. This fluid exchanges the heat between the storage tank and the collector. The fluid used in this system prevents galvanic corrosion which would otherwise arise due to the presence of different metals, and to prevent rusting and scaling. Its density at $20^{\circ} \mathrm{C}$ is 1.092 $\mathrm{kg} / \mathrm{m}^{3}$, and its specific heat is $4.186 \mathrm{~kJ} / \mathrm{kg}{ }^{\circ} \mathrm{C}$. The solar water heating system's performance is investigated and discussed through efficiency parameters. The absorbed energy by the tilted absorber plates and useful energy are calculated by Duffie and Beckman ${ }^{(7)}$.

$S=I_{b} R_{b}(\tau \alpha)_{b}+I_{d}(\tau \alpha)_{d} \frac{1+\cos \beta}{2}+\rho_{g}\left(I_{b}+I_{d}\right)(\tau \alpha)_{g} \frac{1-\cos \beta}{2}$

While Cihan Yıldırım and Ismail Solmus ${ }^{(3)}$ presented the useful energy for the solar water heater:

$Q_{u}=A_{c}\left[S-U_{L}\left(T_{p m}-T_{a m b}\right)\right]=A_{c} F_{R}\left[S-U_{L}\left(T_{i}-T_{a m b}\right)\right]=M_{w 1} C_{p w}\left(T_{o}-T_{i}\right)$

where $U_{L}$ is the overall heat loss coefficient of the solar water heater and it is a sum of top $\left(U_{t}\right)$, bottom $\left(U_{b}\right)$ and edge $\left(U_{e}\right)$ heat loss coefficients.

$U_{L}=U_{t}+U_{b}+U_{e}$

and $\boldsymbol{F}_{\boldsymbol{R}}$ is the heat removal factor which is calculated from the design parameters of water heater ${ }^{(8)}$.

$$
F_{R}=\frac{M_{w 1} C_{p w}}{A_{c} U_{L}}\left[1-\exp \left(-\frac{A_{c} U_{L} F^{v}}{M_{w 1} C_{p w}}\right)\right]
$$

where $\mathrm{F}^{f}$ is the collector efficiency factor ${ }^{(8)}$

$$
\boldsymbol{F}^{\prime}=\frac{\frac{1}{U_{L}}}{W\left\{\frac{1}{U_{L}[D+(W-D) F]}+\frac{1}{C_{b}}+\frac{1}{\pi D_{i} h_{f i}}\right\}}
$$


It represents the ratio of the actual useful energy gain to the useful energy gain that would result if the collector absorbing surface had been at the local fluid temperature. While the collector output temperature can be calculated from the relation given by Soteris kalogirou ${ }^{(8)}$.

$$
T_{o}=T_{i}+\frac{1}{U_{L}}\left[S-U_{L}\left(T_{i}-T_{a}\right)\right]\left[1-\exp \left\{-\frac{A_{c} U_{L} \mathrm{~F}^{\prime}}{\dot{m} C_{p}}\right\}\right]
$$

The evaluation of the collector's performance is deduced by calculating its instantaneous collecting efficiency. According to the well-known Hottel WillierBliss relation, the collector's instantaneous efficiency ${ }^{(9-11)}$ can be expressed as

$$
\eta=F_{R} \tau \alpha-F_{R} U_{L}\left(T_{f i}-T_{a m b}\right) / I
$$

The heat balance equation of the storage tank defines the amount of energy stored inside it and can be written in the form ${ }^{(10)}$.

$$
M C_{p w} \frac{d T_{s}}{d \tau}=m C_{p w}\left(T_{h i}-T_{h o}\right)-m_{L} C_{p w}\left(T_{l}-T_{c l}\right)-U_{s} A_{s}\left(T_{s}-T_{a m b}\right)
$$

The Solar water-heating system efficiency indicates the performance of the solar water heater. The hourly system efficiency can be expressed as

$$
\mathrm{\eta}=\frac{M C_{p w}\left(T_{s f}-T_{s i}\right)}{A_{c} \int I d \tau}
$$

Heat exchanger

Shell and tube heat exchanger was chosen in this system, the principle of operation is simple enough: Two fluids of different temperatures were brought into close contact without mixing each other. One fluid ran through the tubes, and another fluid flew over the tubes (through the shell) to transfer heat between the two fluids. The U-Tube Heat Exchanger was chosen in this study (Fig. 2).

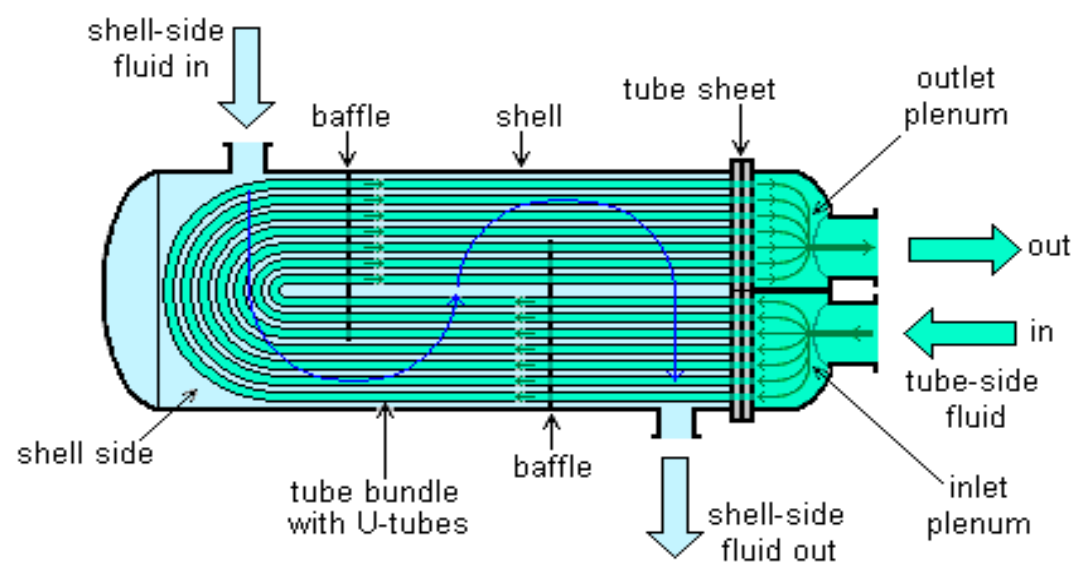

Fig. 2. Layout of a $U$ tube shell and tube heat exchanger.

Egypt. J. Chem. 59, No. 2 (2016) 
The basic equation of the rate of heat transfer of shell and tube heat exchanger can be presented as:

$Q_{T}=\operatorname{UAF}(L M T D)$

where: $\mathrm{Q}_{\mathrm{T}}=$ Total heat load to be transferred, $\mathrm{U}=$ Overall heat transfer coefficient $\mathrm{A}=$ Heat transfer area, $\mathrm{F}=$ Configuration correction factor for multiple tube side and/or shell side passes and LMTD = Logarithmic mean temperature difference.

The fluid rate of heat transfer can be presented as

$$
Q=\dot{m}_{h}{ }^{\circ} C p_{h}\left(T h_{\text {in }}-T h_{\text {out }}\right)
$$

where:

$T h_{i n}=$ Heat exchanger inlet hot water temperature, $T h_{\text {out }}=$ Heat exchanger outlet hot water temperature, $C p_{h}=$ Specific heat of hot water, $\dot{m}_{h}=$ mass flow rate of hot water.

The Logarithmic mean temperature difference (LMTD) can be represented as

$$
L M T D=\frac{\left[\left(T h_{\text {in }}-T c_{\text {out }}\right)-\left(T h_{\text {out }}-T c_{\text {in }}\right)\right]}{\ln \left[\frac{\left(T h_{\text {in }}-T c_{\text {out }}\right)}{\left(T h_{\text {out }}-T c_{\text {in }}\right)}\right]}
$$

where

$T c_{\text {in }}=$ Heat exchanger inlet cold water temperature, $T c_{\text {out }}=$ Heat exchanger outlet cold water temperature, Then the Heat Transfer Area, A can be represented as

$$
A=\frac{Q}{U \times L M T D}
$$

The mass flow rate of cold water can be estimated from the relation of rate of heat transfer

$$
Q=m C p_{C}\left(T c_{\text {out }}-T c_{\text {in }}\right)
$$

The size and number of tubes (for known heat transfer area) can be determined by calculating the surface area per tube , then the number of tubes can be estimated by dividing the total heat transfer area by the surface area per tube.

\section{Atomization chamber}

The atomization chamber is manufactured from sandwich panel galvanized steel sheets of $1 \mathrm{~m} \times 1 \mathrm{~m}$ basin area and $1 \mathrm{~m}$ height. It has an insulated door to clean the scaled salts. The condenser consists of two units. Each unit contains copper tubes with aluminum sheets fins. The cold water used in the condenser unit is provided by the thermoelectric refrigeration cooling water tank. The hot pressurized salt water is flashing inside the atomization chamber and the part of it is evaporated and the rest is falling down in the atomization chamber basin as shown in Fig. 3. 
The input energy to the humidifier side (atomization chamber) equals to the heat of the humid air inside the chamber plus the heat loss from chamber.

$$
\dot{m}_{w}{ }^{\prime} C p_{w}\left(T_{h w i}-T_{w b}\right)=\dot{m}_{a}^{\prime}\left(h_{a i}-h_{a o}\right)+U_{c h} A_{c h}\left(T_{w m}-T_{a}\right)
$$

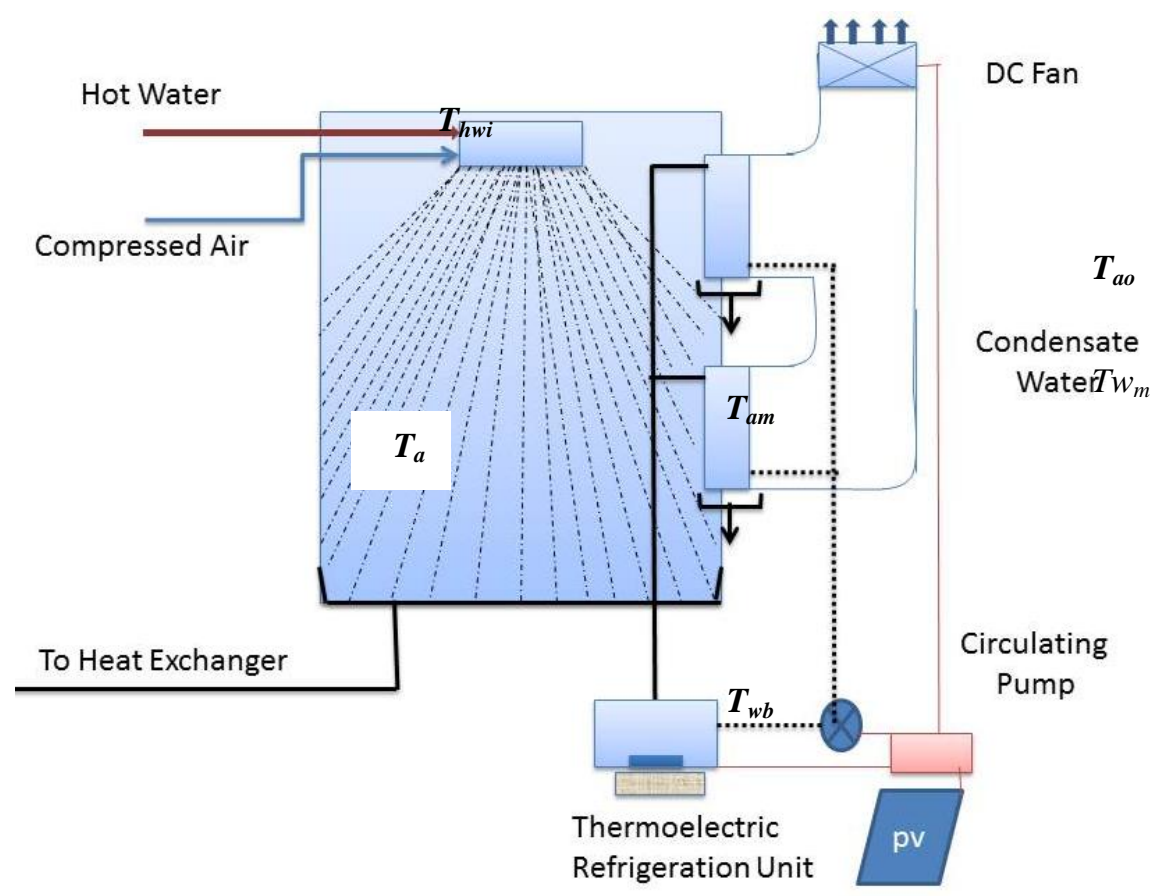

where:

Fig. 3. Atomization chamber components.

$T_{h w i}=$ Atomization chamber inlet hot water temperature

$T_{w b}=$ Atomization chamber basin water temperature

$A_{c h}=$ Atomization chamber surface area

$U_{c h}=$ Atomization chamber heat transfer coefficient

$T_{a} \quad=\quad$ Ambient temperature

The moisture content of the air inside the atomization chamber can be calculated by the equation ${ }^{(3)}$ :

$$
\omega=\frac{0.622 \varphi P_{g}}{P-\varphi P_{g}}
$$

where $P g$ is the saturation pressure of the water vapor and it can be calculated by the following equation ${ }^{(3)}$ :

Egypt. J. Chem. 59, No. 2 (2016) 
$P_{g}=2.7 \times 10^{-9} x T^{5}+2.8 \times 10^{-7} x T^{4}+2.7 x 10^{-5} x T^{3}+0.0014 x T^{2}+0.044 x T+0.61$

Stoecker and Jones ${ }^{(9)}$ presented the air relative humidity $(\varphi)$ in closed enclosure as a function of saturated air temperature $(T)$ using the following empirical correlation:

$\varphi=2.19 \times 10^{-6} T^{3}-1.85 \times 10^{-4} T^{2}+7.06 \times 10^{-3} T-0.077$

The enthalpy of moist air can be expressed as: $h=h_{\alpha}+\omega h_{w}$ where: $h=$ specific enthalpy of moist air $(\mathrm{kJ} / \mathrm{kg}) ; h_{a}=$ specific enthalpy of dry air $(\mathrm{kJ} / \mathrm{kg}) ; \omega=$ moisture content of the air $(\mathrm{kg} / \mathrm{kg}) ; h_{w}=$ specific enthalpy of water vapor $(\mathrm{kJ} / \mathrm{kg})$

Yildırım and Solmus ${ }^{(3)}$ presented the air enthalpy $(h)$ in closed enclosure as a function of saturated air temperature $(T)$ using the following empirical correlation:

$h_{a}=2.82 \times 10^{-5} \times T^{4}-0.00106 \times T^{3}+0.00615 \times T^{2}+1.32 \times T+10.5$

\section{Condenser}

The condensate water mass flow rate leaving from the dehumidifier is calculated by difference of moisture content between the inlet and outlet of the dehumidifier:

$$
\dot{m}_{w}=\dot{m}_{a}(\Delta \omega)
$$

where: $\dot{m}_{w}=$ Condensate water mass flow rate, $\mathrm{kg} / \mathrm{s}$;

$\dot{m}_{a}=$ Air mass flow rate, $\mathrm{kg} / \mathrm{s}$ and

$(\Delta \omega)$

$=$ Difference in moisture content of air inside and outside the atomization chamber in $\mathrm{kg}_{w} / \mathrm{kg}_{d a}$

\section{Thermoelectric refrigerator}

There are five variable parameters affect the operation of the thermoelectric module. These parameters include ${ }^{(13)}$ :

- $\quad$ the input current to the module expressed in amperes, I

- the input voltage to the module expressed in volts, Vin

- $\quad$ the hot side temperature of the module expressed in ${ }^{\circ} \mathrm{K}$, Th

- $\quad$ the cold side temperature of the module expressed in ${ }^{\circ} \mathrm{K}, \mathrm{Tc}$

- the heat input to (or heat pumped by) the module expressed in watts, Qc 


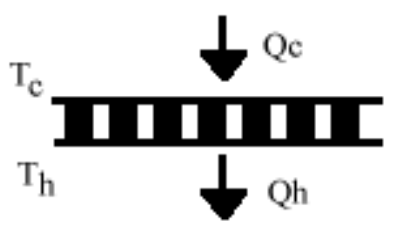

a) The temperature difference (DT) across the module in $\mathrm{K}$ or ${ }^{\circ} \mathrm{C}$ is: $D T=T_{h}-T_{c}$

b) Heat pumped (Qc) by the module in watts is:

$$
Q_{c}=\left(S_{M} \times T_{c} \times I\right)-\left(0.5 \times I^{2} \times R_{M}\right)-\left(K_{M} \times D T\right)
$$

where: $S_{M}$ is the Seebeck coefficient of the module in volts $/{ }^{\circ} \mathrm{K}$ and can be expressed as

$$
S_{M}=S_{1}+S_{2} T+S_{3} T^{2}+S_{4} T^{3}
$$

where: $\quad \mathrm{S} 1=1.33450 \times 10^{-2} ; \quad \mathrm{S} 2=-5.37574 \times 10^{-5}$;

$$
\mathrm{S} 3=7.42731 \times 10^{-7} \text { and } \mathrm{S} 4=-1.27141 \times 10^{-9}
$$

$\mathrm{T}$ is the average module temperature in ${ }^{\circ} \mathrm{K}$.

The electrical resistance of a thermoelectric module, $R_{M}$ as a function of temperature, can be expressed as third order polynomials for the two conditions (a) and (b):

$$
\begin{aligned}
& \text { (a) when DT }=0: \quad R_{M}=r_{1}+r_{2} T+r_{3} T^{2}+r_{4} T^{3} \\
& \text { (b) when DT }>0
\end{aligned}
$$

$$
\begin{gathered}
R_{\text {Mtc }} \text { or } R_{M t h}=r_{1} T+\frac{r_{2} T^{2}}{2}+\frac{r_{\mathrm{g}} T^{s}}{3}+\frac{r_{4} T^{4}}{4} \\
R_{M}=\frac{\left(R_{M t h}-R_{M t c}\right)}{D T}
\end{gathered}
$$

where: RM is the module's resistance in ohms; RMTh is the module's resistance at the hot side temperature Th; RMTc is the module's resistance at the cold side temperature $\mathrm{Tc}$ and $\mathrm{T}$ is the average module temperature in ${ }^{\circ} \mathrm{K}$. In addition: $\mathrm{r} 1=$ $2.08317 ; \mathrm{r} 2=-1.98763 \times 10-2 ; \mathrm{r} 3=8.53832 \times 10-5$ and $\mathrm{r} 4=-9.03143 \times 10-8$, respectively.

The thermal conductance of the thermoelectric module, $K_{M}$ as a function of temperature, can be expressed as third order polynomials for the two conditions (a) and (b):
(a) when DT =0:

$$
K_{M}=k_{1}+k_{2} T+k_{3} T^{2}+k_{4} T^{3}
$$
(b) when $\mathrm{DT}>0$

$$
K_{\text {Mtc }} \text { or } K_{M t h}=k_{1} T+\frac{k_{2} T^{2}}{2}+\frac{k_{g} T^{g}}{3}+\frac{k_{4} T^{4}}{4}
$$

$$
K_{M}=\frac{\left(K_{M t h}-K_{M t e}\right)}{D T}
$$


where: $\mathrm{K}$ is the module's thermal conductance in watts $/{ }^{\circ} \mathrm{K}$; $\mathrm{KMTh}$ is the thermal conductance at the hot side temperature Th; KMTc is the thermal conductance at the cold side temperature $\mathrm{Tc}$ and $\mathrm{T}$ is the average module temperature in ${ }^{\circ} \mathrm{K}$. Moreover:

$\mathrm{k} 1=4.76218 \times 10-1 ; \mathrm{k} 2=-3.89821 \times 10-6 ; \mathrm{k} 3=-8.64864 \times 10-6 \& \mathrm{k} 4=$ $2.20869 \times 10-8$, respectively.

c) The input voltage $\left(V_{i n}\right)$ to the module in volts is:

$$
V_{\text {in }}=\left(S_{M} \times D T\right)+\left(I \times R_{M}\right)
$$

d) The electrical input power (Pin) to the module in watts is: $P_{\text {in }}=V_{\text {in }} \times I$

e) The heat rejected by the module $(\mathrm{Qh})$ in watts is:

$$
Q_{h}=P_{\text {in }}+Q_{C}
$$

f) The coefficient of performance (COP) as a refrigerator is: $C O P=\frac{Q_{C}}{P_{\text {in }}}$

\section{Results and Discussion}

The system is investigated under the meteorological conditions of Cairo, Egypt. The data of dry bulb temperature, wet bulb temperature and relative humidity as well as the solar radiation of a typical day in July, Cairo is shown in Fig. 4 and 5.

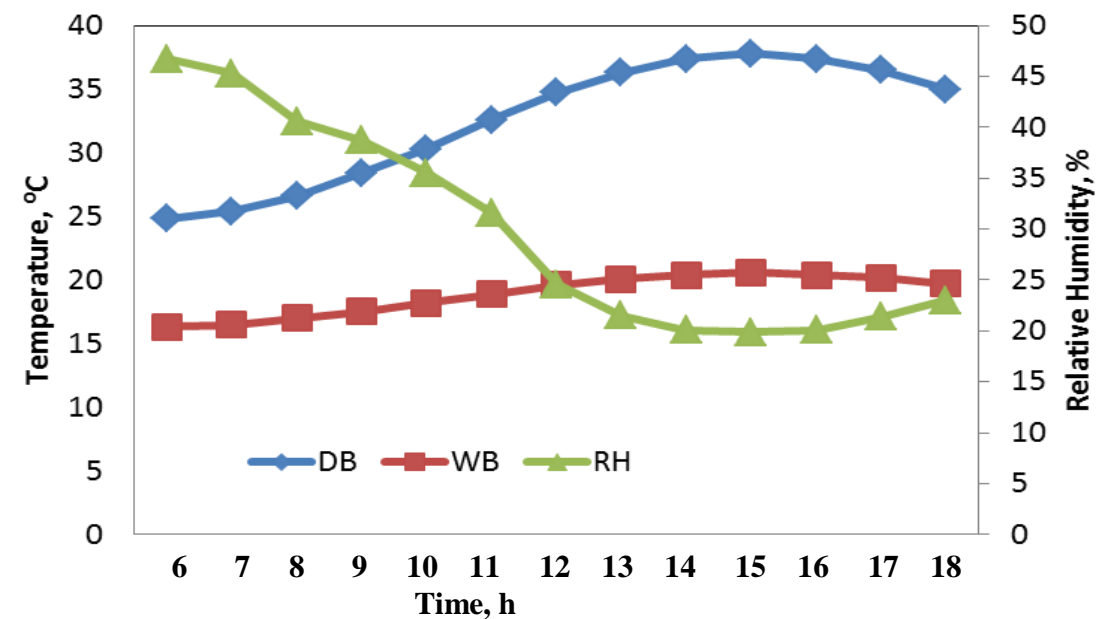

Fig. 4. Meteorological conditions of dry bulb temperature, wet bulb temperature and relative humidity of a typical day in July, Cairo. 


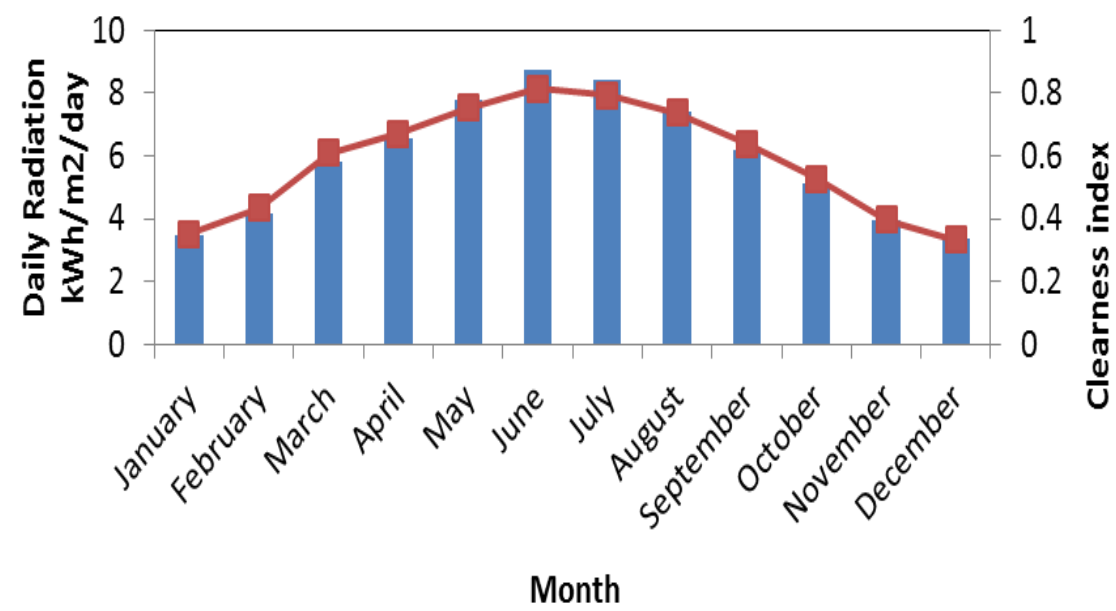

Fig. 5. Meteorological conditions of monthly average daily solar radiation of Cairo.

It is found that the annual average value of solar radiation falling on the horizontal surface of Cairo is $5.88 \mathrm{kWh} / \mathrm{m} 2 /$ day which is a potential value to enhance the solar energy utilization in Egypt. The air enthalpy and relative humidity variations inside and outside the atomization chamber are shown in Fig. 6. It is clear from the figure that at the relative humidity variation during the day time is decreased in the ambient outside the atomization chamber while it is increased inside the atomization chamber due to a large amount of water vapor formed inside the atomization chamber as a result from hot atomized water coming from the solar water storage tank that is mixed with a compressed air in the mixer that placed in the top middle of the atomization chamber. 


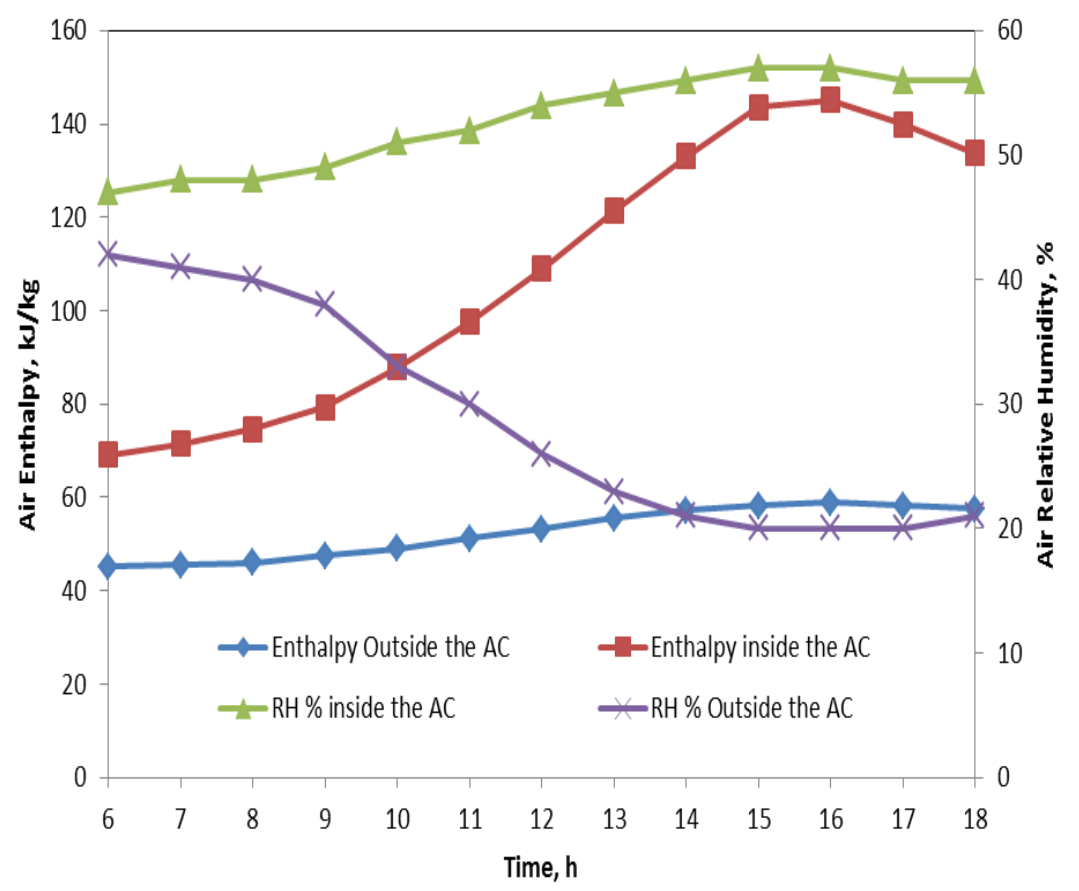

Fig. 6. Air enthalpy and relative humidity variations inside and outside the atomization chamber.

The air temperature variation inside the atomization chamber for different air flow rates is illustrated in Fig. 7. It is clear that increasing the ambient air flow rate affect the air temperature value inside the atomization chamber which consequently decreases the amount of water vapor inside the chamber. While the saturation pressure of water vapor and moisture content variations inside the atomization chamber for different air flow rates is illustrated in Fig. 8 and 9, respectively. It is clear that increasing the ambient air flow rate affect both the saturation pressure of water vapor and moisture content values inside the atomization chamber. For the same amount of the inlet hot water flow rate, when the ambient air flow rate increases the amount of water vapor inside the chamber is decreased and consequently the yield distilled water decreased. The calculated condensed water in the first condenser is estimated hourly and the output data is shown in Fig. 10. It is clear that by increasing the ambient air flow rate, the daily yield water flow rate is decreased and the maximum productivity is achieved with air flow rate equal $0.01 \mathrm{~kg} / \mathrm{s}$ and hot water flow rate equal $0.012 \mathrm{~kg} / \mathrm{s}$. 


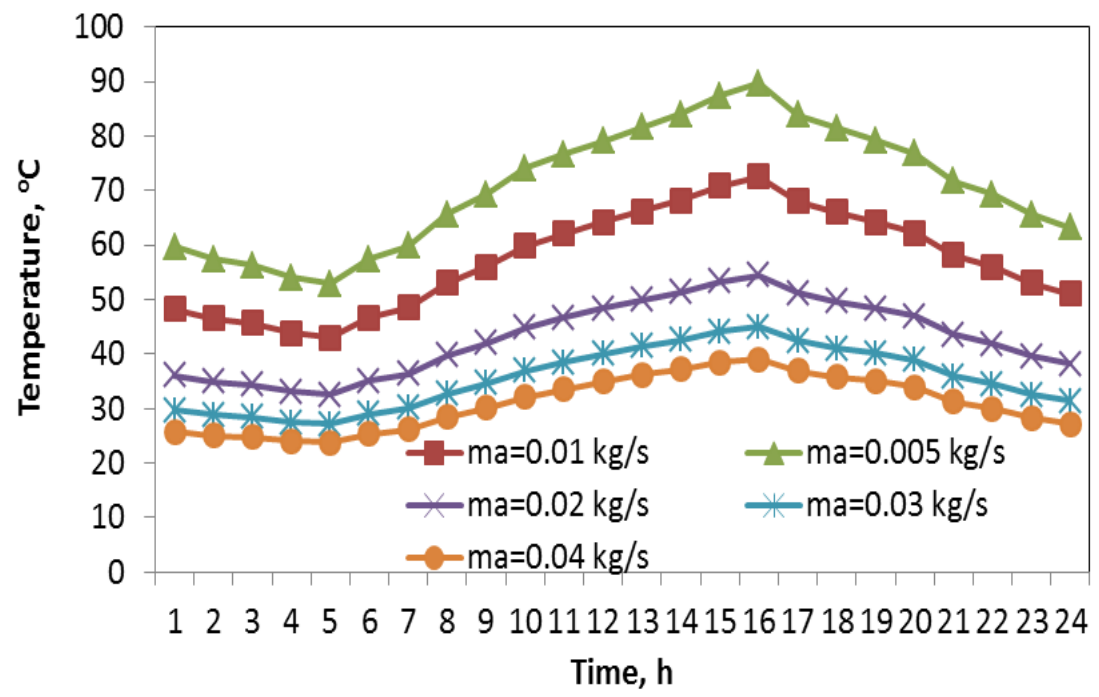

Fig. 7. Air temperature variation inside the atomization chamber for different air flow rates.

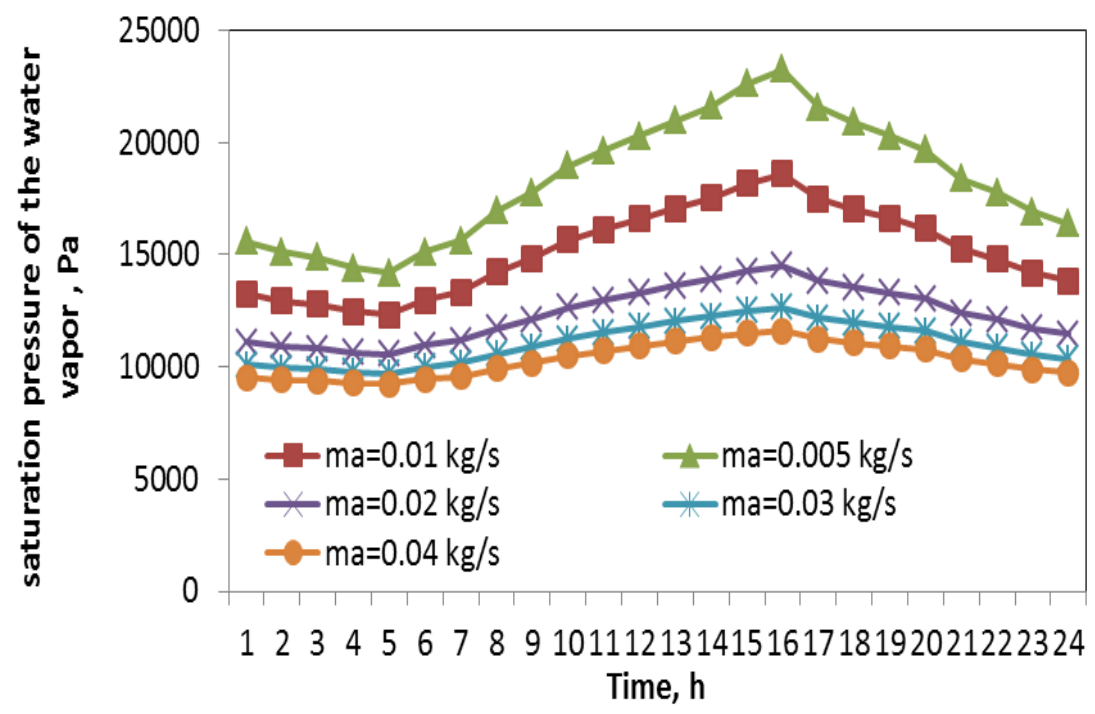

Fig. 8. Saturation pressure of water vapor variation inside the atomization chamber for different air flow rates. 


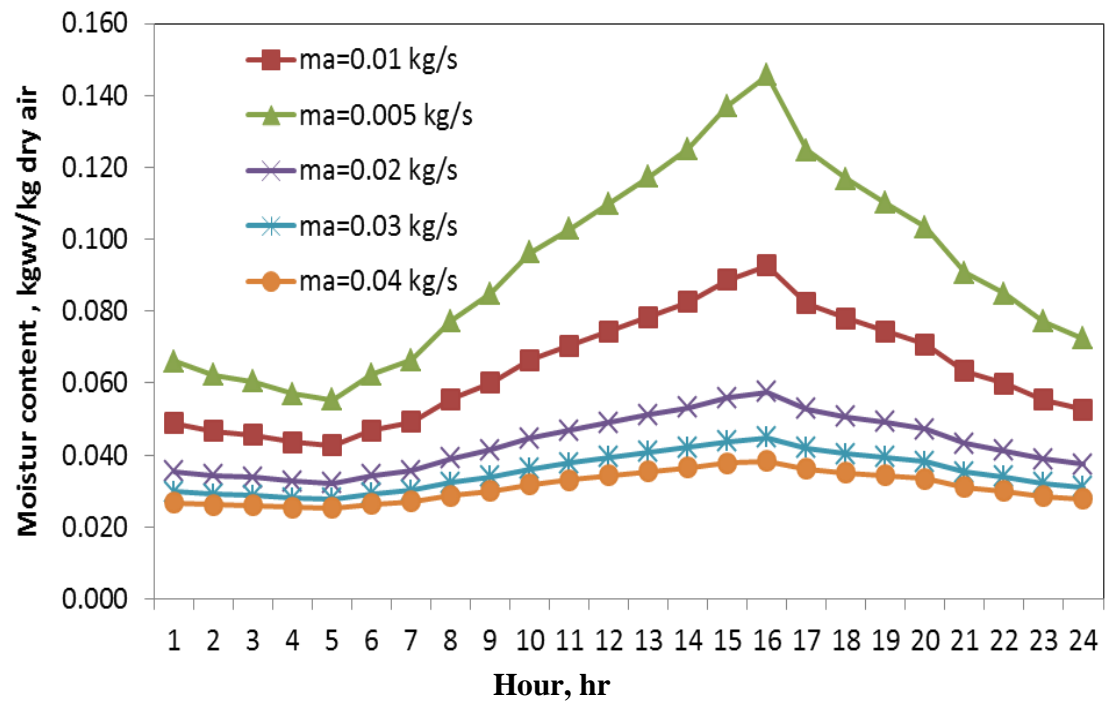

Fig. 9. Moisture content variation inside the atomization chamber for different air flow rates.

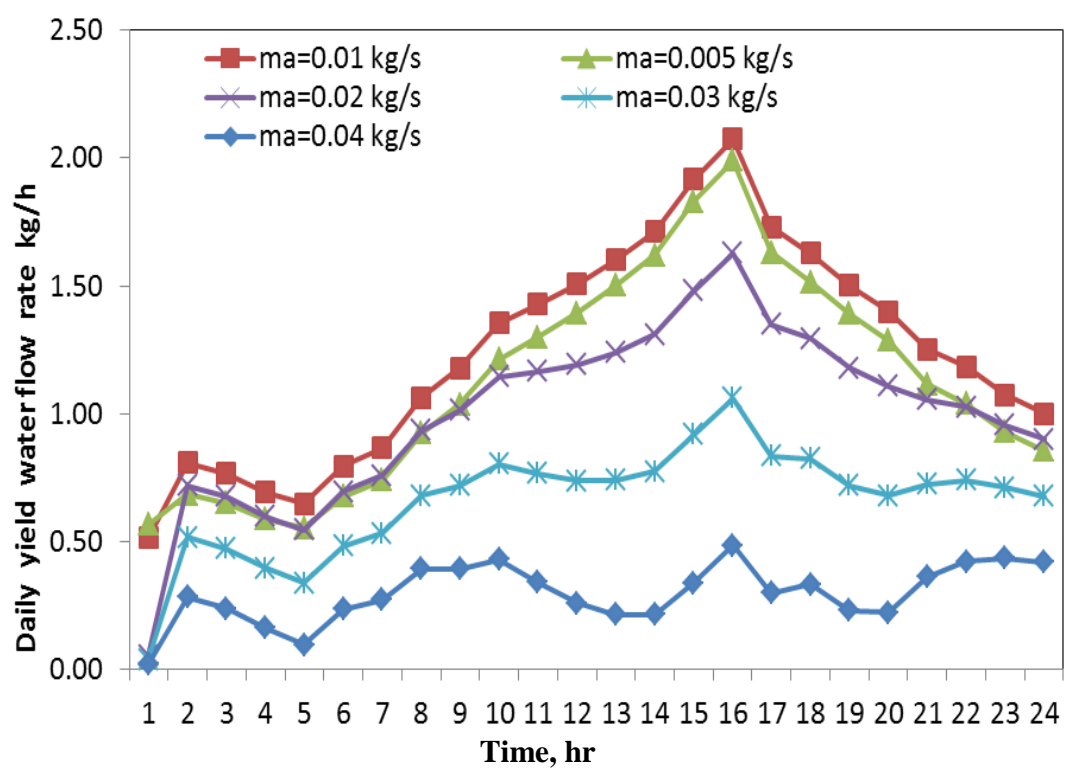

Fig. 10. Condensed water production variation during the day time for the first condenser. 
The maximum productivity also achieved between $3.00 \mathrm{pm}$ and $4.00 \mathrm{pm}$ which is corresponding to the highest water temperature achieved inside the solar water storage tank. The average daily accumulated yield is estimated through the annual variation of solar radiation falling on the collector surface and calculated under different ambient air flow rates as shown in Fig. 11. It is found that the maximum productivity of the system is achieved in summer season with a value of $64.3 \mathrm{~L} /$ day and it is found that each $\mathrm{kWh} / \mathrm{m} /$ day falling on the collector surface produced $7.9 \mathrm{~L} /$ day.

\section{Conclusions}

From the present study, it is concluded that:

1. Water desalination system using humidification-dehumidification process (HDH) enhanced with solar energy is feasible and has good potential in rural coastal areas that need fresh water to be sustained.

2. It is found that the daily production of condensed (fresh) water depends on the saline water flow rate, temperature, air mass flow rate and pressure.

3. It is clear that increasing the ambient air flow rate affects the air temperature value inside the atomization chamber which consequently decreases the amount of water vapor inside the chamber.

4. The maximum productivity also achieved between $3.00 \mathrm{pm}$ and $4.00 \mathrm{pm}$ which is corresponding to the highest water temperature achieved inside the solar water storage tank.

5. It is found that the maximum productivity of the system is achieved in summer season with a value of $64.3 \mathrm{~L} /$ day and it is found that each $\mathrm{kWh} / \mathrm{m} /$ day falling on the collector surface produces $7.9 \mathrm{~L} /$ day.

6. As Egypt enjoys long coastal area of about $2500 \mathrm{~km}$ in length as well as abundant solar energy most time of the year will encourage the Egyptian government to install a several solar water desalination plants with several technologies. One of the most promising and simple technologies is the HDH Process.

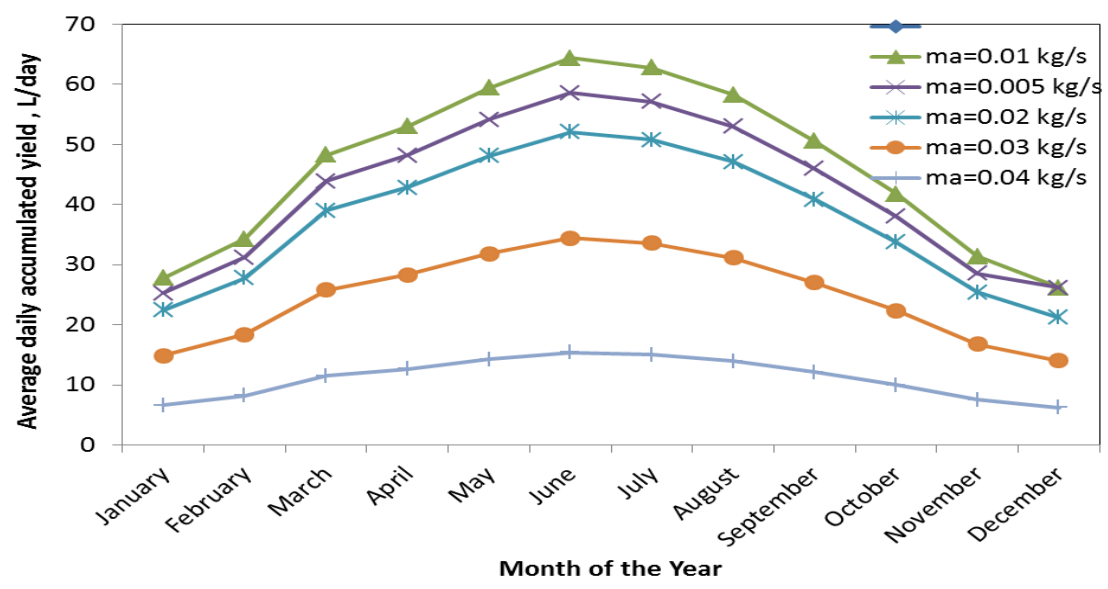

Fig. 11. Average daily accumulated yield through the annual variation of solar radiation.

Egypt. J. Chem. 59, No. 2 (2016) 


\begin{tabular}{|c|c|c|c|}
\hline \multicolumn{4}{|c|}{ Nomenclature } \\
\hline Ac & collector surface area, $\mathrm{m}^{2}$ & $I_{b}$ & beam solar radiation, $\mathrm{W} / \mathrm{m}^{2}$ \\
\hline As & Storage tank surface area, $\mathrm{m}^{2}$ & $I_{d}$ & diffuse solar radiation, $\mathrm{W} / \mathrm{m}^{2}$ \\
\hline$C_{p a}$ & specific heat of air, $\mathrm{J} / \mathrm{kg}^{\circ} \mathrm{C}$ & $M_{a}$ & air mass flow rate, $\mathrm{kg} / \mathrm{s}$ \\
\hline$C_{p w}$ & specific heat of water, $\mathrm{J} / \mathrm{kg}^{\circ} \mathrm{C}$ & $M_{c}$ & $\begin{array}{l}\text { collected clean water mass flow } \\
\text { rate, } \mathrm{kg} / \mathrm{s}\end{array}$ \\
\hline$F_{R}$ & heat removal factor & $M_{w 1}$ & feed water mass flow rate, $\mathrm{kg} / \mathrm{s}$ \\
\hline$F^{\prime}$ & collector efficiency factor & $m_{w l}$ & $\begin{array}{l}\text { mass of water in the storage tank, } \\
\mathrm{kg}, M_{s}\end{array}$ \\
\hline$h_{g}$ & $\begin{array}{l}\text { enthalpy of the saturated water } \\
\text { vapor, } \mathrm{J} / \mathrm{kg}\end{array}$ & $\begin{array}{l}M_{w 2} \\
:\end{array}$ & $\begin{array}{l}\text { water mass flow rate at } \\
\text { humidifier outlet, } \mathrm{kg} / \mathrm{s}\end{array}$ \\
\hline$h_{a i}$ & $\begin{array}{l}\text { enthalpy of air at inlet of the } \\
\text { dehumidifier, } \mathrm{J} / \mathrm{kg}\end{array}$ & $M_{w 3}$ & $\begin{array}{l}\text { cooling water mass flow rate } \\
\text { at dehumidifier inlet, } \mathrm{kg} / \mathrm{s}\end{array}$ \\
\hline$P$ & atmospheric pressure, $\mathrm{kPa}$ & $h_{a o}$ & $\begin{array}{l}\text { enthalpy of air at outlet the } \\
\text { of dehumidifier, } \mathrm{J} / \mathrm{kg}\end{array}$ \\
\hline$P_{g}$ & $\begin{array}{l}\text { saturation pressure of water } \\
\text { vapor, } \mathrm{kPa}\end{array}$ & $T_{i}$ & $\begin{array}{l}\text { fluid inlet temperature of the } \\
\text { water heater, }{ }^{\circ} \mathrm{C}\end{array}$ \\
\hline$R_{b}$ & $\begin{array}{l}\text { ratio of beam radiation on tilted } \\
\text { surface to that on horizontal } \\
\text { surface }\end{array}$ & $T_{o}$ & $\begin{array}{l}\text { fluid outlet temperature of the } \\
\text { water heater, }{ }^{\circ} \mathrm{C}\end{array}$ \\
\hline$S$ & $\begin{array}{l}\text { absorbed energy by the absorber, } \\
\mathrm{W} / \mathrm{m}^{2}\end{array}$ & $T_{a m}$ & ambient temperature, ${ }^{\circ} \mathrm{C}$ \\
\hline$Q_{u}$ & $\begin{array}{l}\text { useful energy gained from the } \\
\text { water heater, } W\end{array}$ & $T_{p m}$ & $\begin{array}{l}\text { mean plate temperature of the } \\
\text { water heater, _C }\end{array}$ \\
\hline$T_{b}$ & temperature of the basin plate, ${ }^{\circ} \mathrm{C}$ & $T_{w l}$ & Temperat ure of feed water, ${ }^{\circ} \mathrm{C}$ \\
\hline$T_{s}$ & $\begin{array}{l}\text { temperature of water storage } \\
\text { tank, }{ }^{\circ} \mathrm{C}\end{array}$ & $T_{w 2}$ & $\begin{array}{l}\text { temperature of water at outlet of } \\
\text { the humidifier, }{ }^{\circ} \mathrm{C}\end{array}$ \\
\hline$T_{w 3}$ & $\begin{array}{l}\text { temperature of cooling water at } \\
\text { inlet of the dehumidifier, }{ }^{\circ} \mathrm{C}\end{array}$ & $T_{w 4}$ & $\begin{array}{l}\text { temperature of cooling water at } \\
\text { outlet of the dehumidifier, }{ }^{\circ} \mathrm{C}\end{array}$ \\
\hline$T_{w 5}$ & $\begin{array}{l}\text { temperature of collected water } \\
\text { gained from the dehumidifier, }{ }^{\circ} \mathrm{C}\end{array}$ & $U_{b}$ & $\begin{array}{l}\text { bottom heat loss coefficient of } \\
\text { the water heater, } \mathrm{W} / \mathrm{m}^{2}{ }^{\circ} \mathrm{C}\end{array}$ \\
\hline$U_{e}$ & $\begin{array}{l}\text { edge heat loss coefficient of the } \\
\text { water heater, } \mathrm{W} / \mathrm{m}^{2}{ }^{\circ} \mathrm{C} \text {; }\end{array}$ & $U_{L}$ & $\begin{array}{l}\text { overall heat loss coefficient of } \\
\text { the water heater, } \mathrm{W} / \mathrm{m}^{2}{ }^{\circ} \mathrm{C} \text {; }\end{array}$ \\
\hline$U_{t}$ & $\begin{array}{l}\text { top heat loss coefficient of the } \\
\text { water heater, } \mathrm{W} / \mathrm{m}^{2}{ }^{\circ} \mathrm{C}\end{array}$ & $\omega$ & $\begin{array}{l}\text { moisture content of air, } k g_{\text {water }} \\
/ k g_{\text {air }}\end{array}$ \\
\hline$\alpha$ & absorptivity & $\rho_{g}$ & ground reflectance \\
\hline$\beta$ & tilt angle, ${ }^{\circ}$ & $\eta$ & efficiency \\
\hline$\varnothing$ & latitude of location, $^{\circ}$ & $\tau$ & transmissivity \\
\hline$\rho_{a}$ & density of air, $\mathrm{kg} / \mathrm{m}^{3}$ & $\varphi$ & relative humidity \\
\hline $\mathrm{W}$ & Distance between riser tubes (m) & $\mathrm{D}$ & Riser tube outside diameter (m); \\
\hline Di & Tube inside diameter $(\mathrm{m})$ & $\mathrm{F}$ & Fin efficiency \\
\hline$h_{f i}$ & $\begin{array}{l}\text { Heat transfer coefficient inside } \\
\text { absorber tube or duct }\left(\mathrm{W} / \mathrm{m}^{2}-{ }^{\circ} \mathrm{C}\right)\end{array}$ & $\mathrm{Cb}$ & Bond conductance $\left(\mathrm{W} / \mathrm{m}-{ }^{\circ} \mathrm{C}\right)$ \\
\hline
\end{tabular}




\section{References}

1. Al-Hallaj, Said, Parekh, Sandeep Farid, M.M. and Selman, J.R., Solar desalination with humidification-dehumidification cycle: Review of economics. Desalination, 195, 169-186 (2006).

2. Abdel Dayem A.M. and Fatouh, M., Experimental and numerical investigation of humidification/ dehumidification solar water desalination systems. Desalination, 247, 594-609 (2009).

3. Cihan Yıldırım and Ismail Solmus, A., Parametric study on a humidificationdehumidification $(\mathrm{HDH})$ desalination unit powered by solar air and water heaters, Energy Conversion and Management, 86, 568-575 (2014).

4. Reza Enayatollahi, Timothy Anderson and Roy Nates, Mathematical modeling of a solar powered humidification dehumidification desalination prototype, Solar The $52^{\text {nd }}$ Annual Conference of the Australian Solar Council (2014).

5. El-Said, E. M. S. and Kabeel, A. E., Theoretical study of a nano-fluid solar collector assisted -hybrid desalination system for small communities needs. Eighteenth International Water Technology Conference, IWTC18 Sharm ElSheikh, 12-14 March (2015).

6. Duffie J.A. and Beckman W.A., Solar Engineering of Thermal Processes. John Wiley and Sons (1980).

7. Al-Ajlan, S., Faris, H.A. and Khonkar, H., A. simulation modeling for optimization of flat plate collector design in Riyadh, Saudi Arabia. Renew Energy,28(9),1325-39 (2003).

8. Soteris Kalogirou, Solar Energy Engineering : Processes and Systems, ISBN 978-012-374501-9, TJ810.K258, (2009).

9. Stoecker, W.F. and Jones, J.W., Refrigeration and Air Conditioning, $2^{\text {nd }}$ ed., Singapore, McGraw Hill, pp. 418-419 (1982).

10. Helwa, N.H., Mobarak, A.M., El Sallak, M.S. and EL-Ghetany, H.H., Effect of hot water consumption on temperature distribution of vertical and horizontal solar water storage tanks.Applied Energy, 52, 185-197 (1995).

11. Mahmoud Shatat, Saffa Riffat and Guohui Gan, An innovative psychometric solarpowered water desalination system. International Journal of Low-Carbon Technologies Advance Access published December 28 (2013).

12. Orfi, J. Laplante, M. Marmouch, H. Galanis, N. Benhamou, B. Ben Nasrallah, S. and Nguyen. C.T., Desalination, 168, 151-159 (2004).

13. https://thermal.ferrotec.com/technology/thermoelectric/thermalRef11

(Received 27/12/2015;

accepted $12 / 1 / 2016)$

Egypt. J. Chem. 59, No. 2 (2016) 


\title{
مقترح نموذج رياضى للتنبؤ بأداء نظام تحلية المياه بالطاقة الشمسية بتقنية الترطيب والتكثيف في مصر بأنر
}

\author{
حمدى الغيطانى و نجوى خطاب \\ قسم الطاقة الثمسية ـ المركز القوى ميى للبحوث ـ الدقى ص ب 12622 ، الجيزة ـ
}

\begin{abstract}
تمت دراسة نظرية لنظام تحلية مياه مبسط يعمل بالطاقة الثمسية باستخدام عملية

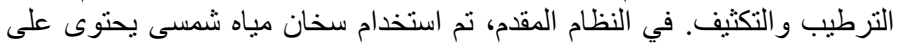

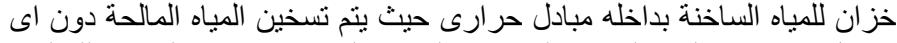

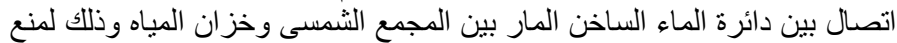

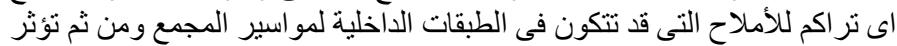

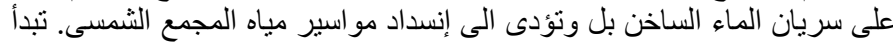

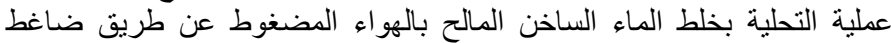

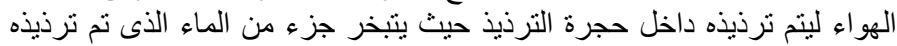

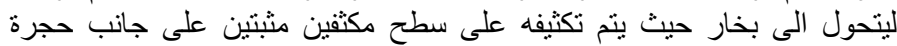

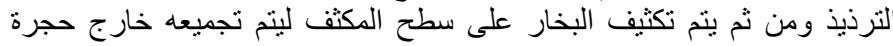

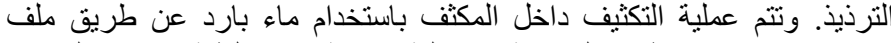

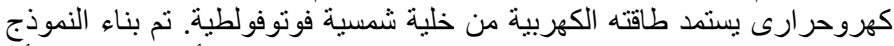

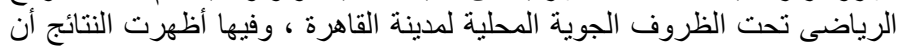

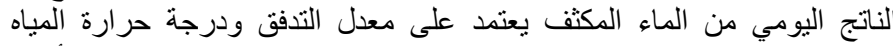

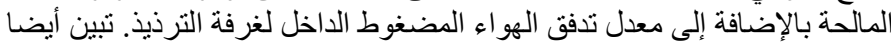

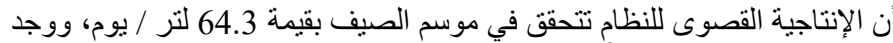

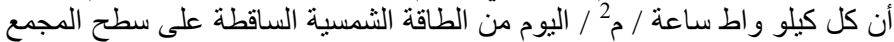

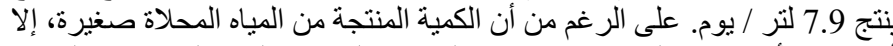

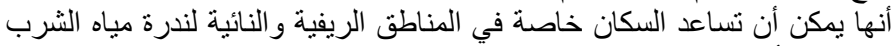

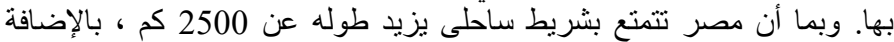

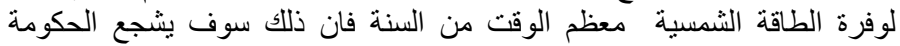

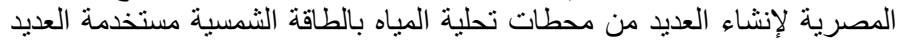

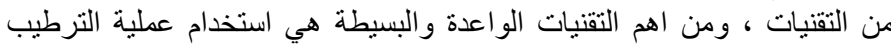
و التكثيف لتحلية المياه باستخدام الطاقة الثمسية.
\end{abstract}

